\title{
A Pilot Study to Evaluate the Magnitude of Association of the use of Electronic Personal Health Records with Patient Activation and Empowerment in HIV-Infected Veterans.
}

Pierre-Cedric Crouch, Carol PhD, RN, FAAN Dawson Rose, Mallory I. Johnson, Susan L Janson, PhD, RN, NP, FAAN

The HITECH Act signed into law in 2009 requires hospitals to provide patients with electronic access to their health information through an electronic personal health record (ePHR) in order to receive Medicare/Medicaid incentive payments. Little is known about who uses these systems or the impact these systems will have on patient outcomes in HIV care. The health care empowerment model provides rationale for the hypothesis that knowledge from an electronic personal health record can lead to greater patient empowerment resulting in improved outcomes.

The objective was to determine the patient characteristics and patient activation, empowerment, satisfaction, knowledge of their CD4, Viral Loads, and antiretroviral medication, and medication adherence outcomes associated with electronic personal health record use in Veterans living with HIV at the San Francisco VA Medical Center.

The participants included HIV-Infected Veterans receiving care in a low volume HIV-clinic at the San Francisco VA Medical Center, divided into two groups of users and non-users of electronic personal health records.

The research was conducted using in-person surveys either online or on paper and data abstraction from medical records for current anti-retroviral therapy (ART), CD4 count, and plasma HIV-1 viral load.

The measures included the Patient Activation Measure, Health Care Empowerment Inventory, ART adherence, provider satisfaction, current CD4 count, current plasma viral load, knowledge of current ART, knowledge of CD4 counts, and knowledge of viral load.

In all, 40 participants were recruited. The use of electronic personal health records was associated with significantly higher levels of patient activation and levels of patient satisfaction for getting timely appointments, care, and information. ePHR was also 
associated with greater proportions of undetectable plasma HIV-1 viral loads, of knowledge of current CD4 count, and of knowledge of current viral load. The two groups differed by race and computer access. There was no difference in the current CD4, provider satisfaction, Health Care Empowerment Inventory score, satisfaction with provider-patient communication, satisfaction with courteous and helpful staff, knowledge of ART, or ART adherence.

The use of electronic personal health records is associated with positive clinical and behavioral characteristics. The use of these systems may play a role in improving the health of people with HIV. Larger studies are needed to further evaluate these associations. 
A Pilot Study to Evaluate the Magnitude of Association of the use of Electronic Personal Health Records with Patient Activation and Empowerment in HIV-Infected Veterans.

Pierre-Cédric B. Crouch, PhD, RN, ANP-BC, ACRN

7 Department of Community Health Systems, University of California, San Francisco

8 San Francisco, CA USA

Carol Dawson Rose, PhD, RN, FAAN

11 Associate Professor, Department of Community Health Systems, University of California, San

12 Francisco

13 San Francisco, CA USA

Mallory Johnson, $\mathrm{PhD}$

16 Associate Professor, Center for AIDS Prevention Studies, University of California, San Francisco

17 San Francisco, CA USA

Susan L. Janson, PhD, RN, ANP-BC, CNS, FAAN

20 Department of Community Health Systems, University of California, San Francisco

21 San Francisco, CA USA

Corresponding Author:

Pierre-Cédric Crouch

1655 Mission St. Unit 643

26 San Francisco, CA 94103

$27 \mathrm{~m}:+1(415) 637-0373$

28 e: pcrouch@sfaf.org 


\section{Abstract}

The HITECH Act signed into law in 2009 requires hospitals to provide patients with electronic access to their health information through an electronic personal health record (ePHR) in order to receive Medicare/Medicaid incentive payments. Little is known about who uses these systems or the impact these systems will have on patient outcomes in HIV care. The health care empowerment model provides rationale for the hypothesis that knowledge from an electronic personal health record can lead to greater patient empowerment resulting in improved outcomes.

The objective was to determine the patient characteristics and patient activation, empowerment, satisfaction, knowledge of their CD4, Viral Loads, and antiretroviral medication, and medication adherence outcomes associated with electronic personal health record use in Veterans living with HIV at the San Francisco VA Medical Center.

The participants included HIV-Infected Veterans receiving care in a low volume HIV-clinic at the San Francisco VA Medical Center, divided into two groups of users and non-users of electronic personal health records.

The research was conducted using in-person surveys either online or on paper and data abstraction from medical records for current anti-retroviral therapy (ART), CD4 count, and plasma HIV-1 viral load.

The measures included the Patient Activation Measure, Health Care Empowerment Inventory, ART adherence, provider satisfaction, current CD4 count, current plasma viral load, knowledge of current ART, knowledge of CD4 counts, and knowledge of viral load.

In all, 40 participants were recruited. The use of electronic personal health records was associated with significantly higher levels of patient activation and levels of patient satisfaction for getting timely appointments, care, and information. ePHR was also associated with greater proportions of undetectable plasma HIV-1 viral loads, of knowledge of current CD4 count, and of knowledge of current viral load. The two groups differed by race and computer access. There was no difference in the current CD4, provider satisfaction, Health Care Empowerment Inventory score, satisfaction with provider-patient communication, satisfaction with courteous and helpful staff, knowledge of ART, or ART adherence.

The use of electronic personal health records is associated with positive clinical and behavioral characteristics. The use of these systems may play a role in improving the health of people with HIV. Larger studies are needed to further evaluate these associations. 
Electronic Personal Health Records (ePHR) are systems that allow patients to access their

79 health information through patient portals linked to their health records. With the passage of the Health

80 Information Technology for Economic and Clinical Health Act (HITECH) in 2009, which provides

81 increased Medicare and Medicaid reimbursement to providers who have adopted Electronic Health

82 Records (EHR) and ePHR, these systems will become commonplace. The law states that these systems

83 must provide a "meaningful use" in order to qualify for incentive payments to implement these

84 systems. There are three stages with specific implementation criteria that are used to define meaningful use. Each stage builds upon the other and sets functional requirements in an EHR that need to be met in

86 order to meet the definition of meaningful use. Stage 2 is currently underway in 2014. To qualify for the incentive payments under meaningful use stage 2, eligible hospitals will need to demonstrate that: (1) $50 \%$ of unique patients were provided with timely online access to their health information, (2) $5 \%$ of unique patients view, download or transmit their health information to a third party, and (3) $5 \%$ of unique patients send a secure message. (Centers for Medicare and Medicaid Services, 2013)

Little is known about the potential impact of electronic access to personal health information on one's sense of health care empowerment and activation to participate in healthcare. However, among patients with HIV, those who are more engaged and empowered in their health care have higher t-cell counts, lower viral loads, greater medication adherence, and participate in less risky behaviors.(Marks et al., 2005; Berg et al., 2005; Park et al., 2007; Metsch et al., 2008; Mugavero et al., 2010; Marshall et al., 2013) Access to personal health information in ePHR systems may help patients with HIV feel more empowered and activated in their health care by providing the knowledge needed to care for themselves. Therefore, the purpose of this study was to explore the patient characteristics, healthcare empowerment, patient activation, and satisfaction associated with electronic personal health record use in Veterans living with HIV under care at the San Francisco VA Medical Center. 
103 The My HealtheVet ePHR is a tethered system that allows all patients at all of the VAMC to have full

104 access to their lab results, progress notes, and medication refills. It also gives patients the ability to

105 send secure messages to their providers at http://www.myhealth.va.gov. Patients are required to have

106 their identity authenticated in person before obtaining access.

\section{Theory}

108 The theory used to guide this research is the Health Care Empowerment Model developed by 109 psychologist Dr. Mallory Johnson in 2011.(Johnson et al., 2012) This model provides a framework that

110 "would enable organization, investigation, and intervention upon factors that contribute to optimal

111 health outcomes" (p. 265). The model of empowerment is comprised of five concepts: engaged,

112 informed, collaborative, committed, and tolerant of uncertainty. These five concepts make up the

113 construct of Health Care Empowerment.

114 The Health Care Empowerment Model can guide research on the value of patient access to ePHR

115 because these systems provide a source of information that can directly impact the patient's

116 engagement in personal health care. The information from the ePHR may result in increased access to

117 care and promote active participation, which may influence engagement in a patient's own health care.

118 The variables collected in this study were selected in reflection of this model and to describe the

119 characteristics of these patients.

\section{Methods}

\section{Study Design}

A cross-sectional observational survey pilot study and chart data abstraction was conducted to

123 describe characteristics of HIV-infected users and non-users of electronic personal health records. The 
124 Committees on Human Research at the University of California, San Francisco approved this study

125 (CHR\# 12-08729), which is the IRB of record for the San Francisco VA Medical Center.

\section{Participants}

127 From September to December 2013, participants were recruited through distribution of flyers

128 describing study eligibility and contact information, electronic health record screening to identify

129 eligible participants, and through healthcare provider referrals. The participants either contacted the

130 researcher directly or they were approached in person while in the waiting room of the dedicated HIV

131 clinic.

132 A non-probability quota sample was used to identify 20 participants who used My HealtheVet

133 and 20 participants who did not use My HealtheVet. Each group was recruited simultaneously until

134 each group was filled. The group was divided by ePHR use only and no other variables. A total sample

135 size of 40 was used as the minimum required for a pilot study to assess associations.(Hertzog, 2008)

136 The inclusion criteria were self-reported HIV infection, ability to speak and understand English, age of

13718 years old or older, status as a military Veteran receiving care at the (SFVAMC), use of the My

138 HealtheVet ePHR system at least twice in the last year (for a subset of 20 participants), and non-use of

139 My HealtheVet ePHR system since its release (for a subset of 20 participants). Participants who lacked

140 capacity to provide informed consent due to active psychosis, cognitive impairment, significant

141 confusion or intoxication were excluded.

142 Setting

143 The San Francisco VA Medical Center provides comprehensive outpatient HIV care to 550

144 Veterans living with HIV in the San Francisco Bay area through services in the Infectious Disease

145 Practice. This clinic is a low volume clinic primarily treating Veterans with HIV and providing

146 infectious disease consultations to non-HIV infected veterans.

147 Study Procedures 
Participants were recruited either during or outside of clinic hours. After determining eligibility

149 and obtaining written informed consent, participants were given the option, depending on their self-

150 reported computer literacy level, to complete either an online questionnaire, paper questionnaire, or

151 have the questionnaire administered to them by the researcher. All participants were informed that the

152 research was optional, had no relationship to their care, and that they could skip any questions that they

153 did not feel comfortable answering in the survey.

154 Measures

155 Demographics and comorbidities were collected using a self-report checklist. Use of the My

156 HealtheVet system was ascertained through self-report and verified in the EHR. Participants were

157 considered users of the system if they had accessed it at least twice within the last 12 months, and had

158 accessed at least one of the available features, such as accessing their health data, ordering medication

159 refills, or sending a secure message to their provider. Access to a computer was measured through self-

160 report. Veterans were considered to have access to a computer based on their self-reported access to

161 computers at home, school, library, or any other source.

162 Patient activation was measured using the Patient Activation Measure (PAM-13). The PAM-13

163 is a 13 item questionnaire with Likert scale responses that assess patient knowledge, skill, and

164 confidence for self-care (Hibbard et al., 2005). The activation score ranges from 0 to 100 and is

165 derived from the raw scores based on Likert responses. There are four levels in the activation score

166 used to identify each participant's stage of activation. Level 1 is scores less than 47, and reflects a

167 participant who may not believe the patient role is important. Level 2 is scores ranging from 47.1 to

168 55.1, and indicates participants who lack the confidence and knowledge to take action. Level 3 is

169 scores ranging from 55.2 to 67.0 , and is for participants who are beginning to take action. Level 4 is

170 scores ranging from 67.1 to 100 , and indicates participants who are "staying the course" under stress. 
171 The PAM-13 is valid and reliable with a Cronbach's alpha of 0.91(Hibbard et al., 2004) and a Rasch

172 person statistic of 0.81 for the real and 0.85 for the model on which it was based. (Hibbard et al., 2005)

173 Patient Empowerment was measured with the Health Care Empowerment Inventory (HCEI).

174 The HCEI is an 8-item questionnaire with Likert scale responses used to assess five hypothesized

175 interrelated facets of the Health Care Empowerment Model.(Johnson et al., 2012) These include:

176 informed, engaged, committed, collaborative, and tolerant of uncertainty. The measure provides two

177 scores: a composite measure of informed, engaged, committed, and collaborative (HCEI_ICCE) and a

178 measure of tolerant of uncertainty (HCEI_Tol). The HCEI is reliable with a rho of 0.78 for

179 HCEI_ICCE and a rho of 0.86 for HCEI_Tol. It also has construct validity demonstrated with factor

180 analysis. (Johnson et al., 2012)

181 Patient satisfaction was measured with the Consumer Assessment of Healthcare Providers and

182 Systems (CAHPS) (version 2.0).(Agency for Health Care Research and Quality, 2013) This survey

183 consists of 14 items, including a single-item global provider rating, and three composite scores

184 measuring three concepts: courteous and helpful office staff, provider-patient communication, and

185 getting timely appointments, care, and information. The single provider rating score is a 1 to 10 on

186 provider satisfaction with a 10 indicating the "best possible provider." The composite satisfaction

187 scores are the mean score of 4-item Likert response of never (1), sometimes (2), usually (3), and

188 always (4) giving an individual item score out of 4 . The concept of courteous and helpful office staff

189 composite score is the mean response of two questions. The concept of provider-patient

190 communication composite score is the mean response of six questions. The concept of getting timely

191 appointments, care, and information composite score is the mean response of five questions. These

192 composite scores have a Cronbach's alpha ranging from .58-.75 and construct validity confirmed with

193 factor analysis.(Hargraves, Hays \& Cleary, 2003) 
195 day adherence measure. The adherence scale uses the Likert responses: all (100\%), most (80\%), about

196 half (50\%), very few (20\%), none (0\%) to assess the self-reported percentage of antiretroviral therapy

197 (ART) taken in the last 7 days. In one previously published study, patients who reported 100\%

198 adherence had higher CD4 counts and lower plasma HIV-1 RNA than those who reported less than

$199100 \%$ indicating criterion validity.(Mannheimer et al., 2002)

$200 \quad$ Knowledge of CD4 counts, plasma viral loads, and ability to identify current ART were

201 determined through survey questions. CD4 counts were considered correct if the participants were able 202 to correctly identify their CD4 counts within the ranges of less than 200, 200-500, and over 500. The 203 research team selected these ranges for their clinical significance to the clinicians and patients.

204 Knowledge of plasma HIV-1 viral loads was considered correct if the participants were able to 205 accurately identify their viral loads as being detectable versus undetectable ( $<40$ copies/ml). Ability to 206 identify ART was considered correct if the participants were able to provide a phonetic spelling of their 207 ART regimen as determined by the investigator. The two groups, My HealtheVet users and non-My HealtheVet users, were compared for

210 differences using bivariate comparisons of the demographic data and characteristic variables. All 211 analyses were conducted using STATA 13.0. T-tests were performed on normally distributed data. 212 Wilcoxon-Mann-Whitney tests were performed on non-normally distributed data. Fisher exact tests 213 and Chi-square tests were performed on proportional data.

\section{Results}


Of the 43 participants approached, 40 (93\%) agreed to participate in the study. There was no

217 missing data in the reported data. The final analyses consist of 20 My HealtheVet users and 20 non-

218 users.

\section{Sample Characteristics}

Table 1 describes the demographic data for all the participants and the two comparison groups.

221 The two groups differed by undetectable plasma HIV-1 RNA, with 19 (95\%) of the My HealtheVet

222 users having an undetectable viral load and 14 (70\%) of the non-My HealtheVet users Fisher=.046.

223 The two groups also differed by race with a Fisher=.01 and access to a computer with a Fisher=.046.

224 There were no differences by age, education, gender (male, female, transgender), current CD4 count, or 225 comorbidities (Diabetes, Hypertension, Depression, Anxiety, PTSD, Hepatitis B, and Hepatitis C).

226 Table 2 describes the users of My HealtheVet who reported a mean satisfaction of $8.1(\mathrm{SD}=2.46)$. The

227 most frequently used service was to refill medications followed by reviewing lab results. The mean

228 number of times My HealtheVet was accessed in the last year was 15.25 times $(\mathrm{SD}=11.76)$.

\section{Outcome Variables}

Table 3 shows the results of the activation, empowerment, satisfaction, and medication

231 adherence variables. The mean PAM-13 score was $67.99(\mathrm{SD}=12.47)$, indicating a level 4 of activation,

232 which constitutes "staying the course" under stress. The mean HECI_ICCE score was 17.35 (SD=2.33)

233 and the mean HCEI_Tol score was $15.93(\mathrm{SD}=2.60)$. The mean provider satisfaction score was 9.22

$234(\mathrm{SD}=1.07)$. The composite satisfaction score for courteous and helpful office staff was $3.59(\mathrm{SD}=0.55)$.

235 The composite score for provider-patient communication was $3.69(\mathrm{SD}=0.42)$. The composite score for 236 getting timely appointments, care, and information was $2.86(\mathrm{SD}=0.71)$. Twenty-five $(63 \%)$ of the 237 participants were able to correctly report their CD4 count. Twenty-seven (68\%) were able to correctly 238 report their HIV viral loads. Eighteen (45\%) were able to correctly report their ART regimens. Thirty239 seven (93\%) reported full adherence to ART. The two groups differed by PAM-13 scores, with My 
240 HealtheVet users reporting a higher mean PAM-13 score of 72.5 (11.27) versus a mean of 63.49

241 (12.23) $\mathrm{z}=2.21, \mathrm{p}=.03$. The My HealtheVet users reported greater satisfaction on getting timely

242 appointments, care, and information with a mean of $3.1(0.6)$ versus a mean of $2.63(0.75) \mathrm{z}=2.15$,

$243 \mathrm{p}=.03$ for the non-users. The My HealtheVet users were able to correctly identify their CD4 counts,

244 with $16(80 \%)$ versus $9(45 \%)$ fisher=.048, as well as their viral loads, with $18(68 \%)$ versus $9(45 \%)$

245 fisher $=.003$. The groups did not differ by HECI_ICCE scores, HCEI_Tol scores, provider satisfaction

246 scores, courteous and helpful office staff scores, provider-patient communication, identifying ART

247 regimen, or reporting $100 \%$ adherence.

248 Digital Divide. The difference of use of ePHR by race and access to computers was suggestive

249 of a digital divide that may have been present in this population, prompting a sub analysis to determine

250 if access to a computer differed by race. The Fisher exact test equaled .171, indicating that access to a

251 computer did not differ by race in this sample. This sub analysis showed that the difference in using

252 My HealtheVet by race was not due to a lack of access to a computer. However, this finding does not

253 exclude the possibility of other racial disparities that may influence the difference in ePHR use.

\section{Discussion}

The use of My HealtheVet is associated with higher levels of activation, lower plasma HIV-1

RNA, greater ability to correctly identify CD4 counts and viral loads, and higher satisfaction in getting

257 timely appointments, care, and information. The two groups also did not differ by adherence to ART.

258 The adherence measure results lacked variability as many reported a high level of adherence, which

259 makes it difficult make conclusions based on this one adherence measure.

The two groups differed by race and access to a computer. This is a significant finding, as

261 patients without access to a computer could never potentially benefit from having access to their health

262 information. This finding indicates the possibility of a digital divide present in the clinic. The Oxford

263 dictionary (2014) defines a digital divide as "the gulf between those who have ready access to 
264 computers and the Internet, and those who do not.” A digital divide present in the clinic could

265 influence the characteristics of ePHR users. While this study was not designed to fully capture a digital

266 divide, the sub analysis indicates that the racial disparity in ePHR use is not associated with having a

267 computer in order to access the ePHR but may be indicative of some other type of barrier.

268 Overall, we speculate that the use of electronic personal health records provides patients with 269 more knowledge and opportunities to participate in their care than traditional visits only care. To our 270 knowledge, this is the first study assessing activation and empowerment of electronic personal health 271 record users in HIV care without any additional interventions. Three previously published studies of 272 ePHR use among HIV infected patients addressed different goals and populations. Those findings 273 indicated that healthy young Caucasian men typically use these systems and that they are largely 274 viewed as useful tools in their care, but some participants expressed concerns about the accuracy of 275 their health data in the ePHR.(Kahn et al., 2010) Mental health and substance abuse issues did not 276 seem to affect a participants' ability to access information online (Hilton et al., 2012). In addition, 277 innovative methods of delivering ePHR though an Apple iPod device were accepted by participants 278 and resulted in greater self-efficacy for self-care. (Luque et al., 2012)

Studies of ePHR in other chronic diseases varied in their findings. The use of ePHR in the context of diabetes care reflected consistently positive findings in biological markers of diabetes control and quality of life. The frequency of ePHR use was found to have a great impact on the outcomes with more frequent users of ePHR having greater improvement in biological markers. (Smith et al., 2004; Hess et al., 2007; Zickmund et al., 2008; Fonda et al., 2009; Holbrook et al., 2009) with hypertension (Green et al., 2008) were found to benefit from the use of ePHR with improved Other conditions also benefited from ePHR. Patients with asthma (van der Meer et al., 2009) or 287 secondary analysis found that frequent users of ePHR had a significantly lower diastolic blood 
288 pressure. Patients undergoing in vitro fertilization (Tuil et al., 2007) or with multiple sclerosis (Miller

289 et al., 2011) did not have any improvement in self-efficacy for self care from the use of ePHR. A study

290 of an internal medicine practice demonstrated improved patient satisfaction of clinic communication

291 and a greater likelihood of using ePHR to send messages about psychosocial issues and information-

292 only messages (Lin et al., 2005).

293

294

295

296

297

298

299

300

301

302

303

304

305

306

307

308

309

310

311 I would like to thank the Veterans at the San Francisco VA who helped make this study a success and 312

\section{Limitations}

The findings of our study should be interpreted with caution. This was a pilot study with a small sample of mostly male military Veterans. The pilot approach was used to explore the knowledge and activation characteristics of patients who use My HealtheVet. The study was not powered to find significant differences in some of the variables. The results demonstrate associations only and do not indicate a causal relationship between ePHR use and health behaviors. The study involved participants who had previously enrolled in the My HealtheVet system, which may demonstrate a pre-existing interest of this cohort in their own care. The study was based on self-reported behaviors of adherence and use of the My HealtheVet ePHR, which is subject to recall bias. The study sample was drawn from an older HIV-Infected and primarily male population receiving care in a highly skilled, low volume setting where providers can spend more time with their patients, introducing attention as another source of potential bias.

Future research is needed to fully address the impact of ePHR in HIV care. A randomized controlled study is needed to determine if ePHR systems can independently cause changes in patient activation. Potential digital divides among populations may also play an important role in determining who is able to benefit from these electronic systems.

\section{Acknowledgments}

my dissertation committee for supporting me during this project. 
313 Note. The views expressed here are those of the authors and not necessarily the views of the 314 Department of Veterans Affairs. This material is the result of work supported with resources and the 315 use of facilities at the San Francisco Veterans Affairs Medical Center. 
319 Agency for Health Care Research and Quality. 2013. Clinician and Group Survey 2.0.

Berg MB, Safren S a, Mimiaga MJ, Grasso C, Boswell S, Mayer KH. 2005. Nonadherence to medical appointments is associated with increased plasma HIV RNA and decreased CD4 cell counts in a community-based HIV primary care clinic. AIDS care 17:902-7.

Centers for Medicare and Medicaid Services. 2013. EHR incentive programs: Stage 2.

Digital Divide: Definition of digital divide in Oxford dictionary (American English) (US) 2014. Oxford Dictionary.

Fonda SJ, McMahon GT, Gomes HE, Hickson S, Conlin PR. 2009. Changes in diabetes distress related to participation in an internet-based diabetes care management program and glycemic control. Journal of Diabetes Science and Technology 3:117-24.

Green BB, Cook AJ, Ralston JD, Fishman PA, Catz SL, Carlson J, Carrell D, Larson EB, Thompson RS, Tyll L. 2008. Effectiveness of home blood pressure monitoring, web communication, and pharmacist care on hypertension control: A randomized controlled trial. JAMA: the Journal of the American Medical Association 299:2857-67.

Hargraves JL, Hays RD, Cleary PD. 2003. Psychometric properties of the Consumer Assessment of Health Plans Study (CAHPS) 2.0 adult core survey. Health services research 38:1509-27.

Hertzog MA. 2008. Considerations in determining sample size for pilot studies. Research in Nursing \& Health 31:180-91.

Hess R, Bryce CL, Paone S, Fischer G, McTigue KM, Olshansky E, Zickmund S, Fitzgerald K, Siminerio L. 2007. Exploring challenges and potentials of personal health records in diabetes selfmanagement: Implementation and initial assessment. Telemedicine and e-Health 13:509-518.

Hibbard JH, Stockard J, Mahoney ER, Tusler M. 2004. Development of the patient activation measure (PAM): Conceptualizing and measuring activation in patients and consumers. Health Services Research 39:1005-26.

Hibbard JH, Mahoney ER, Stockard J, Tusler M. 2005. Development and testing of a short form of the Patient Activation Measure. Health Services Research 40:1918-30.

Hilton JF, Barkoff L, Chang O, Halperin L, Ratanawongsa N, Sarkar U, Leykin Y, Muñoz RF, Thom DH, Kahn JS. 2012. A cross-sectional study of barriers to personal health record use among patients attending a safety-net clinic. PloS one 7:e31888.

Holbrook A, Thabane L, Keshavjee K, Dolovich L, Bernstein B, Chan D, Troyan S, Foster G, Gerstein $\mathrm{H}$, for the COMPETE II Investigators. 2009. Individualized electronic decision support and 
reminders to improve diabetes care in the community: COMPETE II randomized trial. Canadian Medical Association Journal 181:37-44.

Johnson MO, Dawson Rose C, Dilworth SE, Neilands TB. 2012. Advances in the conceptualization and measurement of health care empowerment: Development and validation of the health care empowerment inventory. PloS one 7:e45692.

Kahn JS, Hilton JF, Van Nunnery T, Leasure S, Bryant KM, Hare CB, Thom DH. 2010. Personal health records in a public hospital: Experience at the HIV/AIDS clinic at San Francisco General Hospital. Journal of the American Medical Informatics Association 17:224-228.

Lin CT, Wittevrongel L, Moore L, Beaty BL, Ross SE. 2005. An Internet-based patient-provider communication system: Randomized controlled trial. J Med Internet Res 7:e47.

Luque AE, Corales R, Fowler RJ, Dimarco J, van Keken A, Winters P, Keefer MC, Fiscella K. 2012. Bridging the Digital Divide in HIV Care: A Pilot Study of an iPod Personal Health Record. Journal of the International Association of Physicians in AIDS Care:Advance online publication.

Mannheimer S, Friedland G, Matts J, Child C, Chesney M. 2002. The consistency of adherence to antiretroviral therapy predicts biologic outcomes for human immunodeficiency virus-infected persons in clinical trials. Clinical Infectious Diseases 34:1115-21.

Marks G, Crepaz N, Senterfitt JW, Janssen RS. 2005. Meta-Analysis of High-Risk Sexual Behavior in Persons Aware and Unaware They are Infected With HIV in the United States. JAIDS Journal of Acquired Immune Deficiency Syndromes 39:446-453.

Marshall R, Beach MC, Saha S, Mori T, Loveless MO, Hibbard JH, Cohn J a, Sharp VL, Korthuis PT. 2013. Patient Activation and improved outcomes in HIV-infected patients. Journal of general internal medicine.

Van der Meer V, Bakker MJ, van den Hout WB, Rabe KF, Sterk PJ, Kievit J, Assendelft WJJ, Sont JK. 2009. Internet-based self-management plus education compared with usual care in asthma: A randomized trial. Annals of Internal Medicine 151:110-20.

Metsch LR, Pereyra M, Messinger S, Del Rio C, Strathdee S a, Anderson-Mahoney P, Rudy E, Marks G, Gardner L. 2008. HIV transmission risk behaviors among HIV-infected persons who are successfully linked to care. Clinical Infectious Diseases 47:577-84.

Miller DM, Moore SM, Fox RJ, Atreja A, Fu AZ, Lee J-C, Saupe W, Stadtler M, Chakraborty S, Harris CM, Rudick RA. 2011. Web-Based self-management for patients with multiple sclerosis: A practical, randomized trial. Telemedicine and e-Health.

Mugavero MJ, Davila JA, Nevin CR, Giordano TP. 2010. From access to engagement: Measuring retention in outpatient HIV clinical care. AIDS Patient Care and STDs 24:607-13. 
383 Park WB, Choe PG, Kim S-H, Jo JH, Bang JH, Kim HB, Kim NJ, Oh M, Choe KW. 2007. One-year adherence to clinic visits after highly active antiretroviral therapy: A predictor of clinical progress in HIV patients. Journal of internal medicine 261:268-75.

386 Smith KE, Levine BA, Clement SC, Hu M-J, Alaoui A, Mun SK. 2004. Impact of MyCareTeam for poorly controlled diabetes mellitus. Diabetes Technology \& Therapeutics 6:828-835.

Tuil WS, Verhaak CM, Braat DDM, de Vries Robbé PF, Kremer JAM. 2007. Empowering patients undergoing in vitro fertilization by providing Internet access to medical data. Fertility and Sterility 88:361-8.

391 United States Department of Veterans Affairs. 2013. My healthevet. health records and hypertension control: A randomized trial. Journal of the American Medical Informatics Association : JAMIA 19:626-34.

395 Zickmund S, Hess R, Bryce C, McTigue K, Olshansky E, Fitzgerald K, Fischer G. 2008. Interest in the use of computerized patient portals: Role of the provider-patient relationship. Journal of General Internal Medicine 23:20-26. 


\section{Table $\mathbf{1}$ (on next page)}

Sample Characteristics and Subsample Comparisons 
2 Table 1 Sample Characteristics and Subsample Comparisons

\begin{tabular}{|c|c|c|c|c|}
\hline Variable & All $n=40$ & $\begin{array}{l}\text { My HealtheVet } \\
\text { User } n=20\end{array}$ & $\begin{array}{l}\text { My HealtheVet } \\
\text { Non-user } n=20\end{array}$ & Statistics \\
\hline Age in years & $44.65(10.28)$ & $42.5(10.82)$ & $46.8(9.49)$ & $\mathrm{t}=-1.34(38) \mathrm{p}=.19$ \\
\hline $\mathrm{CD} 4$ cell $/ \mathrm{ml}^{3}$ & $580.73(254.68)$ & $515.15(263.94)$ & 646.3(233.28) & $\mathrm{z}=-1.73, \mathrm{p}=.08^{*}$ \\
\hline On ART & $40(100 \%)$ & $20(100 \%)$ & $20(100 \%)$ & Fisher $=1.00$ \\
\hline $\begin{array}{l}\text { Undetectable Plasma } \\
\text { HIV-1 RNA }\end{array}$ & $33(83 \%)$ & $19(95 \%)$ & $14(70 \%)$ & Fisher $=.046$ \\
\hline $\begin{array}{l}\text { Gender } \\
\text { Male } \\
\text { Female } \\
\text { Transgender } \\
\text { Male to Female }\end{array}$ & $\begin{array}{l}39(98 \%) \\
0 \\
1(2 \%)\end{array}$ & $\begin{array}{l}19(95 \%) \\
0 \\
1(5 \%)\end{array}$ & $\begin{array}{l}20(100 \%) \\
0 \\
0\end{array}$ & Fisher $=1.00$ \\
\hline $\begin{array}{l}\text { Hispanic } \\
\text { Yes } \\
\text { No }\end{array}$ & $\begin{array}{l}6(15 \%) \\
34(85 \%)\end{array}$ & $\begin{array}{l}3(15 \%) \\
17(85 \%)\end{array}$ & $\begin{array}{l}3(15 \%) \\
17(85 \%)\end{array}$ & Fisher $=1.00$ \\
\hline $\begin{array}{l}\text { Race } \\
\text { Caucasian } \\
\text { African American } \\
\text { Native American } \\
\text { Other }\end{array}$ & $\begin{array}{l}31(77.5 \%) \\
4(10 \%) \\
2(5 \%) \\
3(7.5 \%)\end{array}$ & $\begin{array}{l}19(95 \%) \\
0 \\
1(5 \%) \\
0\end{array}$ & $\begin{array}{l}12(60 \%) \\
4(20 \%) \\
1(5 \%) \\
3(15 \%)\end{array}$ & Fisher $=.01$ \\
\hline $\begin{array}{l}\text { Education } \\
\text { Less than HS } \\
\text { HS/GED } \\
\text { Some College } \\
\text { 2-year College } \\
\text { 4-year College } \\
\text { Masters Degree } \\
\text { Doctoral Degree }\end{array}$ & $\begin{array}{l}1(2.5 \%) \\
8(20 \%) \\
7(17.5 \%) \\
8(20 \%) \\
10(25 \%) \\
4(10 \%) \\
2(5 \%)\end{array}$ & $\begin{array}{l}0 \\
4(20 \%) \\
3(15 \%) \\
2(10 \%) \\
7(35 \%) \\
3(15 \%) \\
1(5 \%)\end{array}$ & $\begin{array}{l}1(5 \%) \\
4(20 \%) \\
4(20 \%) \\
6(30 \%) \\
3(15 \%) \\
1(5 \%) \\
1(5 \%)\end{array}$ & Fisher $=.45$ \\
\hline Diabetes & $9(22.5 \%)$ & $5(25 \%)$ & $4(20 \%)$ & Fisher $=1.00$ \\
\hline Depression & $11(27.5 \%)$ & $6(30 \%)$ & $5(25 \%)$ & $\begin{array}{l}\operatorname{chi}^{2}=0.07(1), \mathrm{p}= \\
0.8\end{array}$ \\
\hline Anxiety & $5(12.5 \%)$ & $2(10 \%)$ & $3(15 \%)$ & Fisher $=0.66$ \\
\hline PTSD & $2(5 \%)$ & $1(5 \%)$ & $1(5 \%)$ & Fisher $=1.00$ \\
\hline
\end{tabular}




\begin{tabular}{|c|c|c|c|c|}
\hline HTN & $24(60 \%)$ & $14(70 \%)$ & $10(50 \%)$ & $\begin{array}{l}\operatorname{chi}^{2}=1.67(1), \mathrm{p}= \\
0.2\end{array}$ \\
\hline $\mathrm{HBV}$ & $14(35 \%)$ & $4(20 \%)$ & $10(50 \%)$ & Fisher $=0.09$ \\
\hline $\mathrm{HCV}$ & $8(20 \%)$ & $4(20 \%)$ & $4(20 \%)$ & Fisher $=1.00$ \\
\hline Computer Access & 33 & 19 & 14 & Fisher $=.046$ \\
\hline
\end{tabular}




\section{Table 2 (on next page)}

My HealtheVet User Characteristics 
2

3 Table 2 My HealtheVet User Characteristics

\begin{tabular}{ll}
\hline Variable & My HealtheVet User $n=20$ \\
\hline & \\
MHV Satisfaction & $8.1(2.46)$ \\
MHV Frequency in Last Year & $15.25(11.76)$ \\
& \\
$\underline{\text { Uses }}$ & \\
Secure Messaging & $9(45 \%)$ \\
Review Labs & $10(50 \%)$ \\
Review Notes & $6(30 \%)$ \\
Review Appointments & $8(40 \%)$ \\
Refill Medications & $18(90 \%)$ \\
& \\
\hline
\end{tabular}

4

5 


\section{Table 3 (on next page)}

Activation, Empowerment, Satisfaction, and Adherence Outcomes 
2 Table 3 Activation, Empowerment, Satisfaction, and Adherence Outcomes

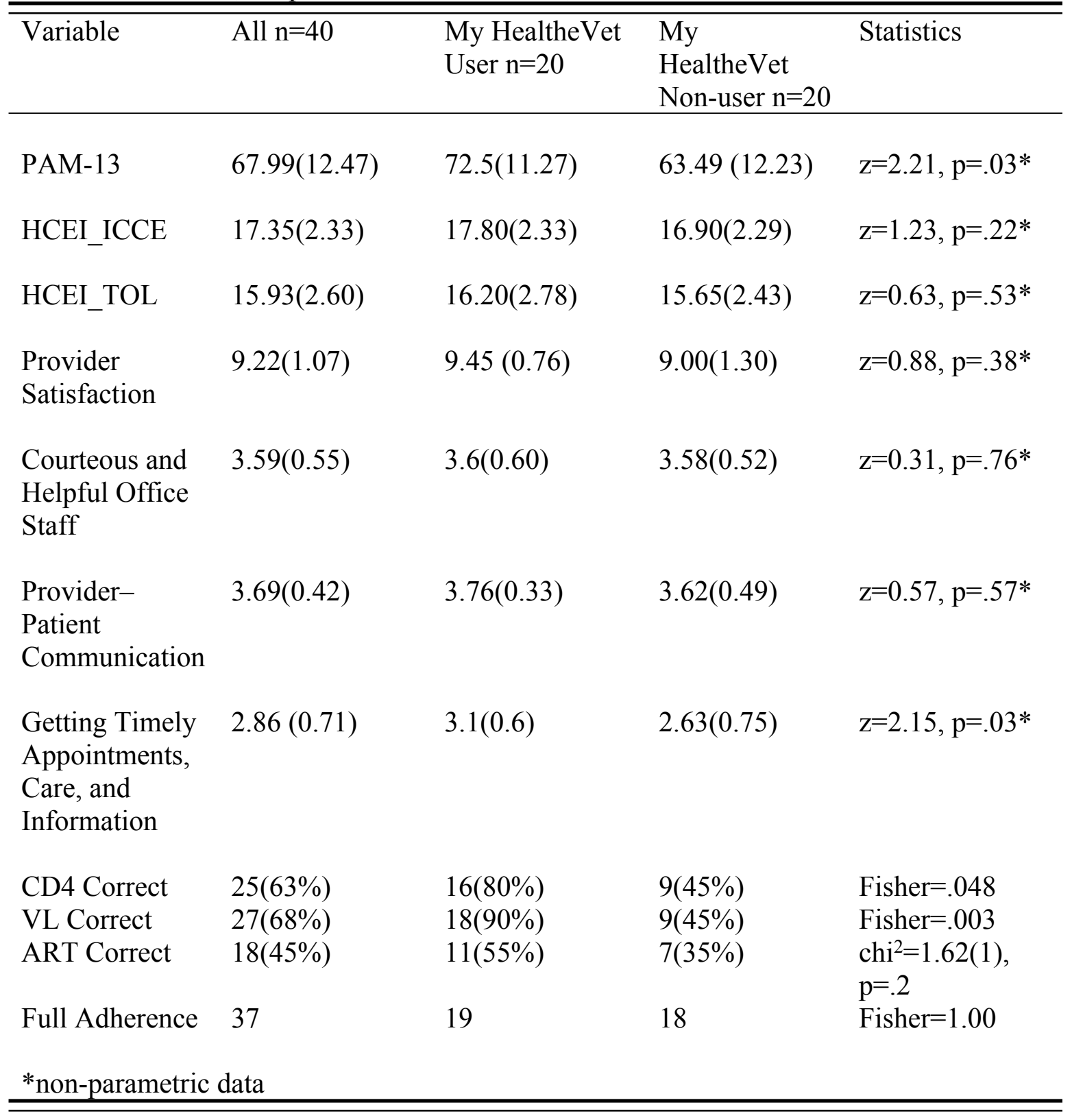

